\title{
Promoting The Teaching and Learning of English Language in Nigeria for National Development: A Case Study of Etsako Regions of Edo State of Nigeria
}

\author{
Acheoah, John Emike (PhD) ${ }^{1}$, Adeoye, Adeyinka Olusola ${ }^{2}$ \\ Department of Language and Communication Studies, Faculty of Arts, Management and Social Sciences, Federal \\ University, Dutsin-ma, Nigeria \\ Department of English, Faculty of Humanities, Ajayi Crowther University, Oyo, Nigeria.
}

\begin{abstract}
:
The Nigerian learners study English towards acquiring discrete skills. However, the final destination of many career-driven learners of English is the Nigerian work-force. Their productivity determines the development of the country. This paper contends that "no nation develops more than its standard of education, which inevitably, is determined by the language of formal education. To aid this study, questionnaires are administered to 120 respondents from the study areas: Akoko-Edo, Etsako West, Owan East and Owan West Local Government Areas of Edo State of Nigeria. Data are analyzed using frequency and percentage. Hinging on the Projection Principle, the study finds that proper teaching and learning of English in schools, fosters social mobilization, participation in governance, national cohesion and effective performance at work places.
\end{abstract}

Keywords: Teaching English, learning English, formal education, national development, Etsako

\section{INTRODUCTION}

Although English Language is Nigeria's lingua franca, more efforts are needed to teach it in schools before its full developmental potentials can be achieved in the country. It is unfortunate that those who speak English in Nigeria far below native-like control of grammatical, phonological and pragmatic competencies to claim literacy in the language. Indeed, competency in the use of English Language presupposes having adequate speaking, reading and writing skills. The project of enhancing linguistic competence in English studies has remained a matter of rhetoric and intellectual tournament for decades. Negative attitudes towards langusge, be it indigenous or alien, impacts on the potency of language in nation-building. Adegbija (2004, p.54) submits: "Attitudes towards languages are motivated by several factors including their socio-economic value, their status-raising potentials, their perceived instrumental value, their perceive esteem, their perceived functions or roles in the nation, their numerical strength, the perceived political and economic power of its speakers, their use in the official domains, their educational value, ..." So long as success is the aggregate of inputs, goal-driven approach towards locating the place of English, Nigeria's National Language in nation-building will facilitate the teaching and learning of the language. Realizing the importance of English in Mass Literacy, the government of Nigeria formulated Adult Education policies; literacy in English is not outside the objectives of such policies. However, the extremely low literacy level in English became a major set-back in the pedagogical process. Failure rate in English at the Ordinary Level examinations is therefore not incidental. Adegoju (2009, p.5) notes that "Nigerian government has focused on teaching of science and technology to the neglect of language education."

This study investigates the pedagogical situation and implications of English studies in Nigeria, using Etsako regions of Edo State as case study. These Etsako regions include: Akoko-Edo, Etsako West, Owan East and Owan West Local Government Areas of Edo State of Nigeria, which are occupied by the Afenmai (Etsako) people; see Oseni (2003) for more geographical tips about the Afenmai people. The Projection Principle which has to do with using selected samples of study to make logical conclusions about macro status-quo (cf. Jolayemi 2000). This paper views education as a major facet of national development, and so hinges on it, to investigate the importance of effective teaching and learning of English Language as a subject or course in primary, secondary and tertiary institutions in the country towards meaningful and sustainable development. The pride of place which English has in

${ }^{1}$ Corresponding Author: actualemike@gmail.com 
Nigeria has necessitated its study at different levels of formal education in the country. To ensure adequate mastery of the discrete skills of the language, the different level-based Curriculums of formal education emphasize teaching of vocabulary, writing, grammar, etc. Unfortunately, these skills are not adequately mastered by Nigerian learners.

\section{The Problem}

Despite the general awareness that many students or pupils do not perform well in English Language examinations, adequate efforts are not made to curb the trend. If schools continue to teach English Language towards literacy rather than proficiency, development will be hindered in the country ${ }^{1}$. For decades, the government of Nigeria has not been able to find solutions to the falling standard of education in the country. In addition, the government is still running a futile mission towards nation-building. This paper contends that Nigeria's development can be achieved via a language therapy within the context of exploring the country's lingua franca, English. If the government does not provide incentives for teaching English towards both literacy and proficiency, Nigeria's overall development will be crippled.

\section{iII. Promoting English Studies in Nigeria}

For good performance in English Language examinations at all levels of formal education, the subject has to be effectively taught. Facilitators of effective teaching and learning of English Language as a subject in primary and secondary schools, or as a course in tertiary institutions (e.g. Phonology, Morphology and Syntax) include: proficient teachers, well prepared curriculums, proper test instruments, positive attitudes, adequate and conducive classrooms, laboratories, efficient monitoring of activities by school authorities, pragmatic government involvement, scholarships and healthy academic competitions.

\section{METHODOLOGY}

In this study, questionnaires are administered to 150 respondents; 50 copies were given to students, teachers and civil servants respectively, in the study area. It is instructive that the researcher selects these three categories of respondents: gathering information about the teaching and learning of English Language presupposes involving students and teachers rather than other categories of people in the Nigerian society; planning and policy issues concerning language presupposes engaging civil servants who are either legislating or implementing national policies, including those of language. Out of the 150 data administered, 120 are randomly selected; 40 from each category of respondents. The data are analyzed via frequency and percentage. They are rated on a five-point scale of Strongly Agree (SA), Agree (A), Undecided (U), Strongly Disagree (SD) and Disagree (D). However, rather than considering all the five scales in the explanation of phenomena, each scale is selected according to its relevance in the interpretive process as in Table 1 below where each statement is presented with a single relevant scale tagged "remark":

Table1. Statistics of 120 Respondents

\begin{tabular}{|c|c|c|}
\hline Statement & Remarks & Frequency and Percentage \\
\hline $\begin{array}{l}\text { 1. English is not satisfactorily taught and learnt in Nigerian } \\
\text { schools at all levels. } \\
\text { 2. Students, teachers, school authorities and government } \\
\text { do not adequately facilitate the teaching and learning of } \\
\text { English in Nigerian schools. } \\
\text { 3. Promoting the teaching and learning of English in } \\
\text { Nigerian schools does not foster national development. } \\
\text { 4. English does not promote national unity. }\end{array}$ & $\begin{array}{l}\text { Agree } \\
\text { Agree } \\
\text { Disagree } \\
\text { Disagree }\end{array}$ & $\begin{array}{l}\text { Frequency }=105 \\
\text { Percentage }=87.5 \% \\
\text { Frequency }=108 \\
\text { Percentage }=90 \% \\
\text { Frequency }=92 \\
\text { Percentage }=76.6 \% \\
\text { Frequency }=86 \\
\text { Percentage }=71.6 \%\end{array}$ \\
\hline $\begin{array}{l}\text { 5. Illiteracy and poor performance at work places can be } \\
\text { reduced if English is effectively explored as a medium of } \\
\text { instruction in schools in Nigeria. } \\
6 \text {. Teachers' mastery of discrete skills of English is not } \\
\text { instrumental to students' good performance in } \\
\text { examinations. } \\
\text { 7. Social mobilization is not enhanced when the chunk of }\end{array}$ & $\begin{array}{l}\text { Disagree } \\
\text { Disagree } \\
\text { Agree }\end{array}$ & $\begin{array}{l}\text { Frequency }=92 \\
\text { Percentage }=76.6 \% \\
\text { Frequency }=110 \\
\text { Percentage }=91.6 \% \\
\text { Frequency }=22\end{array}$ \\
\hline
\end{tabular}




\section{American Research Journal of English and Literature, Volume 1, Issue 4, 2015} ISSN 2378-9026
Nigerians are competent in English.
8. Concepts in school subjects or courses are better
understood by students who are vast in the vocabulary of English

\begin{tabular}{|l|l} 
Disagree & $\begin{array}{l}\text { Percentage }=18.3 \% \\
\text { Frequency }=10 \\
\text { Percentage }=8.3 \%\end{array}$
\end{tabular}

Table 1 indicates that $87.5 \%$ of respondents agree that English is not satisfactorily taught and learnt in Nigeria schools at all levels. This situation is inimical to development. If teachers are either inadequate or incompetent, the corpora of English produced will be substandard.

In Item 2 (Statement 2) where $76.6 \%$ of respondents agree that students, teachers, school authorities and government do not adequately facilitate teaching and learning of English, it can be concluded that: it takes concerted efforts to promote teaching and learning of English; teachers should be professional; school authorities should be strict in maintaining standard and utilizing funds; the government should provide adequate incentives and evolve viable, context-sensitive language policies.

It is clear in Item 3 that $76.6 \%$ (92 out of 120) of respondents think that promoting teaching and learning of English fosters national development. Thus, these ones view sustainable national development in terms of a nation's language policy and its implementation on the part of government and school authorities.

Item 4 reveals that 86 out of 120 respondents do not accept the submission that English does not promote national unity. Indeed, these respondents acknowledge the role of lingua franca which unlike indigenous Nigeria languages does not have divisive potentials.

Statement 5 declares that literacy impinges on national growth; $93.3 \%$ of respondents agree that illiteracy and poor performance at work places can be reduced if English is effectively explored as a medium of instruction in schools in Nigeria. Obviously, the $87.5 \%$ of respondents who submit that English is not satisfactorily taught and learnt in Nigeria (in Item 1), implies that presently, there is mass illiteracy in Nigeria, in addition to poor performance at work places.

Item 6 is a thought-provoking indication that teacher's mastery of discrete skills of English informs students' good performance; as much as $91.6 \%$ of respondents disagree to the statement.

It is significant that only $18.3 \%$ of respondents agree that social mobilization is not the product of competence in English; these respondents are aware of the integrative function of a nation's lingua franca. They also acknowledge the non-divisive potentials of English in multilingual Nigeria.

Evidently, $8.3 \%$ of respondents disagree to item 8, and this means that there is meaningful relationship between lessons and concepts (which teachers use in conveying such lessons). Thus, teacher-pupil mastery of the vocabulary of English facilitates teaching and learning of the subject. Indeed, poor teaching and learning of English in Nigeria results in: limited access to knowledge; low output in workplaces; lack of social mobilization; and ethnic resentments.

Scholars who contend for the teaching of English as a core subject in the Curriculum of schools (as entrenched in the Federal Constitution of 1979 as well as that of 1999), and acknowledge the language as a critical instrument of Nigeria's development include: Butari (2010), Ugoji (2010), Tamuno (1978) as well as Ayodabo and Acheoah (2013).

See Emenajo (2010) for insights on the technological implications of literacy in a National Language. English is worth being studied extensively considering the following factors:

$>$ It has undergone graphisation (standardized orthography);

$>$ The numeration system of English is modernized (the decimal principle operates);

$>$ English is potent as a metalanguage (being able to function as a medium of instruction in schools);

$>$ The language is widely used in television and radio broadcasting;

$>$ It is the language of literary writing.

It is wrong, though common, to view development as a concept that is restricted to science and technology. Nigeria's development is therefore, not necessarily her innovations or inventions in science and technology. One cannot restrict Nigeria's development to her ability to manufacture cars, weapons of mass destruction, aircrafts, 
drugs with high-profile efficacy, medical breakthrough of diverse kinds, and so on. Development has to do with "advancements in the scheme of things": science, technology, administration, education, culture, trade, human relations, judiciary, broadcasting, journalism, law enforcement, etc. Due to space constraints, we cannot expand the table below, which illustrates how English impacts on the Nigerian work-force towards national development:

Table2. Structure of Development

\begin{tabular}{|l|l|l|}
\hline Discrete Skills & Domains & Notes \\
\hline $\begin{array}{l}\text { Segmental } \\
\text { Phonemes }\end{array}$ & Broadcasting & $\begin{array}{l}\text { Articulating consonant and vowel sounds correctly, facilitates } \\
\text { understanding pieces of information in news. Thus, the public is } \\
\text { rightly informed and mobilized. }\end{array}$ \\
\hline $\begin{array}{l}\text { Supra-segmental } \\
\text { Phonemes }\end{array}$ & Interdisciplinary & $\begin{array}{l}\text { People communicate intended messages when stress and intonation are } \\
\text { correctly placed in utterances. A question may be misconstrued as a } \\
\text { statement when rendered with a falling tune rather than a rising tune. }\end{array}$ \\
\hline Prepositions & Judiciary & $\begin{array}{l}\text { A Lawyer should not use the preposition "for" when he means } \\
\text { "against" as this will destroy the credibility of his case, to the } \\
\text { detriment of his client. }\end{array}$ \\
\hline Tense & Interdisciplinary & $\begin{array}{l}\text { In different speech situations, speakers of English have to reflect the } \\
\text { actual time of predications. This is effective communication for the } \\
\text { overall good of society. Whereas "peace" is a facilitator of } \\
\text { development, Misunderstood linguistic structures create strife and } \\
\text { division in society. }\end{array}$ \\
\hline Writion & $\begin{array}{l}\text { In primary, secondary and tertiary institutions, teachers depend on } \\
\text { appropriate vocabulary to disseminate information to learners of } \\
\text { different subjects or courses. The teacher's choice of words is } \\
\text { determined by learners' level of understanding (cognitive maturity) as } \\
\text { well as the topic of a particular lesson. }\end{array}$ \\
\hline
\end{tabular}

Table 1 explains the structure of development. The advancement from an $\mathrm{x}$ curve to a y curve (where $\mathrm{x}$ and $\mathrm{y}$ are indefinite, infinite states-of-affairs) in different domains of national life, means that Nigeria is developing. The table also shows that mastery of discrete skills of Standard English (whether Standard British English Standard Nigerian English) impacts on national development.

\section{RESULTS}

The results of the study are as follows:

$>$ Lack of competent teachers impacts negatively on literacy in English;

$>$ Promoting the teaching and learning of English in Nigeria presupposes the active participation of teachers, school authorities and governments;

$>$ English is widely believed to have developmental potentials in Nigeria;

$>$ Performance of the Nigerian workforce partly depends on effective teaching and learning of English;

$>$ Like science and technology, language has vital roles to play in nation-building, and English in Nigeria is not an exception.

\section{CONCLUSIONS AND RECOMMENDATIONS}

The significance of teaching and learning English for Nigeria's development was acknowledged in the study area. By extension therefore, this study concludes that English is instrumental to the overall development of Nigeria if students, teachers, school authorities and government play their roles effectively. For the development of Nigeria, the teaching of English has to be adequately planned in terms of the various contexts of language planning identified by scholars: the socio-political context, the psychological context, the administrative (government/political) context and the educational context. However, committed experts are supposed to be engaged in language planning. Proper planning in this regard includes language maintenance and assigning of functions to a 


\section{American Research Journal of English and Literature, Volume 1, Issue 4, 2015 ISSN 2378-9026}

language. Sociolinguists acknowledge that language can be viewed as a problem in post-colonial Africa, despite its instrumentality. Different factors account for poor teaching, learning and assessing of English in primary, secondary and tertiary institutions in the country: many learners are not serious; many teachers are incompetent; schools lack facilities; test instruments are not appropriate; inimical attitudinal and environmental factors bedevil the pedagogical process; there is weak government participation.

The recommendations of this study are as follows:

$>$ There should be periodic workshops for teachers at all levels of formal education, to update their knowledge of teaching techniques;

$>$ Class population has to be significantly reduced for result-oriented teaching and learning of English Language, bearing in mind, the uneven academic abilities of the ESL (English as a Second Language) learners2

$>$ Education should be affordable, so that the teeming population of Nigerians who need proficiency or literacy in English to thrive in their respective careers will have their desires met4;

$>$ Test instruments in English Language should be reliable;

> The English Curriculums of different levels of formal education in Nigeria should be reviewed periodically3;

$>$ The government should be actively involved in school management or administration by evolving productive policies and providing incentives at all levels of formal education.

\section{Notes}

$>$ The quality of English that is instrumental to national development transcends the corpora produced via literacy in the subject. Therefore, there is urgent need to promote the teaching and assessing of English Language, Nigeria's National Language.

$>$ In classes where pupils or students are few, teachers can easily teach and ascertain learners' abilities through marked tests. On the other hand, teachers avoid administering tests to an extremely large class, since they are not ready to mark same. Thus, individual attention which is a facilitator of the pedagogical process is not operative in some schools.

$>$ Periodic review facilitates the construction of valid and reliable test instruments to the ESL learners of English in Nigeria. Validity is concerned with whether a test measures what it is intended to measure. Reliability on the other hand, is concerned with the extent to which we can depend on the test results.

\section{ACKNOWLEDGEMENTS}

This paper was first presented in March $24^{\text {th }} 2015$, at the Annual Faculty of Arts Lecture of the Obafemi Awolowo University, Ile Ife. Appreciation is hereby expressed to the organizers for accommodating the paper. The participants are also apreciated for their objective criticisms which have improved the paper.

\section{Appendix}

\section{Questionnaire}

Dear Respondent,

We are conducting a research titled "Teaching, Learning and Promoting English Language in Nigeria for National Development: A Case Study of Etsako Region s of Edo State"

Your sincere responses to the questions in questionnaire will be useful.

Acheoah, John Emike (PhD)

$\&$

Adeoye, Adeyinka Olaoye

(Researchers) 
American Research Journal of English and Literature, Volume 1, Issue 4, 2015

ISSN 2378-9026

\section{SECTION A}

\section{Preliminary Information}

Please tick (/) in the boxes as appropriate.

Age (Years):

$<20()$

$20-29()$

$30-39()$

$40-49()$

$50-59()$

$>60()$

\section{Gender:}

Male

Female

\section{Education:}

School Certificate

OND/NCE

First Degree/HND

Masters Degree

$\mathrm{PhD}$

Status:

Student

Teacher

Civil Servant

\section{SECTION B}

Each statement is provided with a five-point scale: Strongly Agree (SA), Agree (A), Undecided (U), Strongly Disagree (SD) and Disagree (D). Kindly tick an item (statement) as appropriate.

\begin{tabular}{|c|c|c|c|c|c|c|}
\hline S/No. & Statement & & Scale & & & \\
\hline & & SA & $\mathbf{A}$ & $\mathbf{U}$ & SD & D \\
\hline 1. & English is not satisfactorily taught and learnt in Nigerian schools at all levels. & & & & & \\
\hline 2. & $\begin{array}{l}\text { Students, teachers, school authorities and government do not adequately } \\
\text { facilitate the teaching and learning of English in Nigerian schools. }\end{array}$ & & & & & \\
\hline 3. & $\begin{array}{l}\text { Promoting the teaching and learning of English in Nigerian schools does not } \\
\text { foster national development. }\end{array}$ & & & & & \\
\hline 4. & Mastery of English does not promote national unity. & & & & & \\
\hline 5. & $\begin{array}{l}\text { Illiteracy and poor performance at work places can be reduced if English is } \\
\text { effectively explored as a medium of instruction in schools in Nigeria. }\end{array}$ & & & & & \\
\hline 6. & $\begin{array}{l}\text { Teachers' mastery of discrete skills of English is not instrumental to students' } \\
\text { good performance in examinations. }\end{array}$ & & & & & \\
\hline 7. & $\begin{array}{l}\text { Social mobilization is not enhanced when the chunk of Nigerians are competent } \\
\text { in English. }\end{array}$ & & & & & \\
\hline 8. & $\begin{array}{l}\text { Concepts in school subjects or courses are better understood by students who are } \\
\text { vast in the vocabulary of English. }\end{array}$ & & & & & \\
\hline
\end{tabular}




\section{American Research Journal of English and Literature, Volume 1, Issue 4, 2015 \\ ISSN 2378-9026}

\section{REFERENCES}

[1] Adegbija, E. (2004). "Language Policy and Planning in Nigeria." Current Issues in Language Planning. 5(3), 1-66.

[2] Adeyemi, Adegoju. (2009). "Language Teaching, Learning and Utility: A Triadic Paradigm for Revitalising Indigenous Nigerian Languages." International Journal of Language Society Culture, Issue 27.

[3] Ayodabo, J. O. \& Acheoah,, J. E. (2013). "Nigerian English in a Decolonized State: Prospects and Constraints." International Journal of Arts and Humanities, Volume 2, Issue 2: 48 - 52.

[4] Butari, U. (2010). "The English Language and Literacy as Basic Tools for National Development'(pp.33-50) in Ndimele (Ed.) English Studies and National Development in Nigeria. ELTAN

[5] Emenajo, N. (2010). "Functional Illiteracy: The Bane of National Development" (pp.1-32) in Ndimele (Ed.) English Studies and National Development in Nigeria. ELTAN

[6] Gheddo, Piero (1973). Why is the Third World Poor? (Translated by Kathryn Sullivan). Orbis Books. Maryknoll, New York.

[7] Jolayemi, D. (2000). "Language and Style: A Systematic Text-linguistic Study of Olu Obafemi'sPlays” in Oni D, Ododo S. eds. Larger than His Frames: Critical Studies and Reflection on Olu Obafemi. Lagos: Centre for Black and African Arts and Civilization, National Theatre, p. 118.

[8] Oseni Z.I. (2003). Afenmai Proverbs. Auchi. Darun-Nur.

[9] Tamuno, N. (1978). In Ubahakwe, E. (Ed.) (1979) The Constitution of the Federal Republic of Nigeria. Federal Government Press, Apapa, Lagos.

[10] Ugoji, S. (2010). “The English Language and Development in Nigeria.” (pp.93-107) in Ndimele Ed.) English Studies and National Development in Nigeria. ELTAN United Nations Information Centre, (2005) www.unhchr.ch/unhr/lang/pcn.htm 